\title{
Vitrectomy in the management of intraocular foreign bodies and their complications
}

\author{
GHOLAM A. PEYMAN, ${ }^{1}$ MOTILAL RAICHAND, ${ }^{2}$ \\ MORTON F. GOLDBERG, ${ }^{1}$ AND STEVE BROWN ${ }^{1}$ \\ From the ${ }^{1}$ Department of Ophthalmology, University of Illinois Eye and Ear Infirmary, \\ and ${ }^{2}$ Cook County Hospital, USA
}

SUMMARY Twenty-six eyes with intraocular foreign bodies (IOFB) and/or their sequelae were treated by pars plana vitrectomy and associated surgery. One-step removal of the IOFB in combination with pars plana vitrectomy resulted in early visual rehabilitation and minimal complications. Of 11 eyes with IOFB treated by primary vitrectomy at the time of IOFB removal 20/50 or better visual acuity was obtained in $10(91 \%)$. Four of these eyes had retinal injury, 3 of which were successfully repaired without subsequent complication and with retention of good visual function. In 3 eyes IOFBs were not removed owing to chronic retinal encapsulation. These eyes continue to retain good visual acuity, and ERG studies show no evidence of retinal toxicity. Of 12 eyes in which vitrectomy was performed for sequelae of IOFB only $5(41 \%)$ showed visual improvement better than $20 / 50$. Only in 2 of 7 eyes with tractional retinal detachment could the retina be reattached. In cases of retinal injury primary vitrectomy, cryocoagulation, and scleral buckling are suggested for prevention of late traction retinal detachment.

\begin{abstract}
A magnetic intraocular foreign body (IOFB) in the posterior segment has traditionally been removed by the pars plana method, ${ }^{1-3}$ the direct posterior method, ${ }^{4}$ or rarely the anterior approach through a corneal incision. ${ }^{56}$ In the presence of hyphaema, lens opacities, and vitreous haemorrhage and in the case of nonmagnetic IOFBs, the surgery of IOFB can present many problems. ${ }^{78}$ The use of automated vitrectomy instruments has greatly facilitated the surgery of IOFB. ${ }^{9-11}$ We describe various techniques, including use of the vitrophage, by which we managed IOFB removal and associated sequelae. $^{12-15}$
\end{abstract}

\section{Materials and methods}

\section{PATIENTS}

Between 1973 and 1978, 26 patients were referred to us for the removal of an IOFB or for complications caused by previous removal of IOFB. Patients ranged in age from $2 \frac{1}{2}$ to 60 years. All were male. The majority of injuries, caused by flying pieces of metal while hammering or chiselling, occurred when the patients were at work. The perforating

Correspondence to Dr Gholam A. Peyman, University of Illinois Eye and Ear Infirmary, $1855 \mathrm{~W}$ Taylor Street, Chicago, IL 60612, USA. injuries ranged from self-sealing wounds to severe corneoscleral or scleral lacerations, with intraocular bleeding and vitreous and/or uveal prolapse.

For the purpose of this report we divided our patients into 3 groups. Group 1 (11 cases) had sustained recent perforating ocular injury caused by an IOFB. These patients had a 1-step operation including removal of an IOFB, vitrectomy-lensectomy, and repair of retinal injury if one was present. Group 2 (3 cases) had retained IOFB of long duration and were referred because of late complications of cataractous and vitreous opacities. Group 3 (12 cases) had an IOFB previously removed and then after varying time intervals were referred to us for management of complications, such as traumatic cataracts, vitreous opacity, and retinal detachment.

\section{SURGICAL TECHNIQUES}

Preoperative evaluation includes detailed ocular examination, appropriate $x$-ray studies, and ultrasound examination (mainly by $B$ scan). In acute cases for which emergency surgery is performed cultures of the conjunctival cul-de-sac and wound margins are obtained. Local anaesthesia is used for most patients. However, children and apprehensive adults are operated under general anaesthesia.

The surgical technique depends on the nature of 

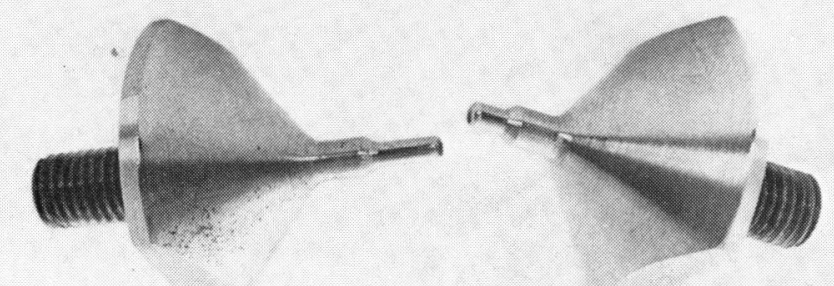

Fig. 1 Peyman-Raichand intraocular magnetic tip with $3 \mathrm{~mm}$ intraocular extension (right) and $6 \mathrm{~mm}$ intraocular extension (left). the IOFB, whether it is magnetic or nonmagnetic, its size, and the presence of retinal damage. Additional factors influencing the management are damage to the lens and the extent of opacities in the vitreous. Before removal of the IOFB corneal, scleral, and other ocular injuries are treated as necessary.

A 360 limbal peritomy is made, and 4-0 bridle sutures are passed under the bellies of the 4 rectus

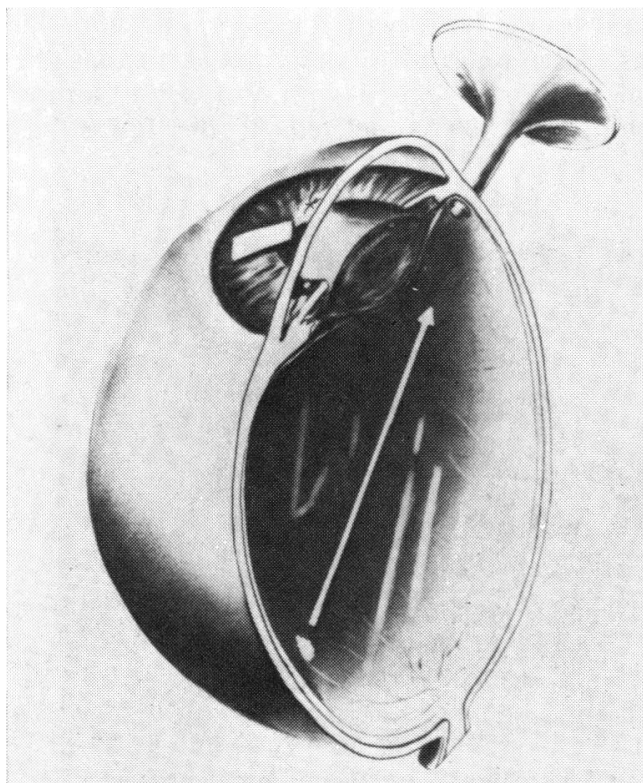

Fig. 2 Magnetic intraocular foreign body extraction by intraocular magnetic tip. muscles. The scleral surface is examined to rule out occult or double perforation. A $4 \mathrm{~mm}$ sclerotomy, usually in the inferior temporal quadrant, is made 3 to $4 \mathrm{~mm}$ behind the limbus. A no. 15 Bard-Parker blade is used to cut the sclera to the uveal tract. The underlying ciliary body is cauterised. A mattress suture is passed through the lips of the sclerotomy, and a loose double-throw knot is applied. A no. 52S Beaver blade is passed through the sclerotomy into the vitreous and then removed after making a few slicing motions. In our series lensectomy was performed in all cases except case 2 in Table 3.

\section{MAGNETIC EXTRACTIONS OF IOFB}

When dealing with a magnetic IOFB an intraocular magnetic tip (Fig. 1) is introduced into the vitreous through the sclerotomy, and, if the IOFB is in the vitreous or minimally embedded on the surface of the retina, it is removed by this manoeuvre (Fig. 2). The magnetic tip is then withdrawn, and a wideangle cutter vitrophage is introduced into the vitreous, and the mattress suture is tightened.

After a lensectomy an attempt is made to remove as much vitreous as possible. The retina is examined for retinal tears or retinal detachment which might have resulted from the IOFB or the surgical procedure. The vitrophage is removed, and the scleral mattress suture is tightened. The conjunctival peritomy is closed, and mydriatric and antibiotic drops are instilled in the conjunctival cul-de-sac.

\section{FORCEPS EXTRACTION}

A standard sclerotomy is performed as described earlier and the vitrophage is inserted into the vitreous cavity. If the IOFB is floating freely in the 
Fig. 3 Small intraocular foreign body being sucked through the cutting portal of the vitrophage.

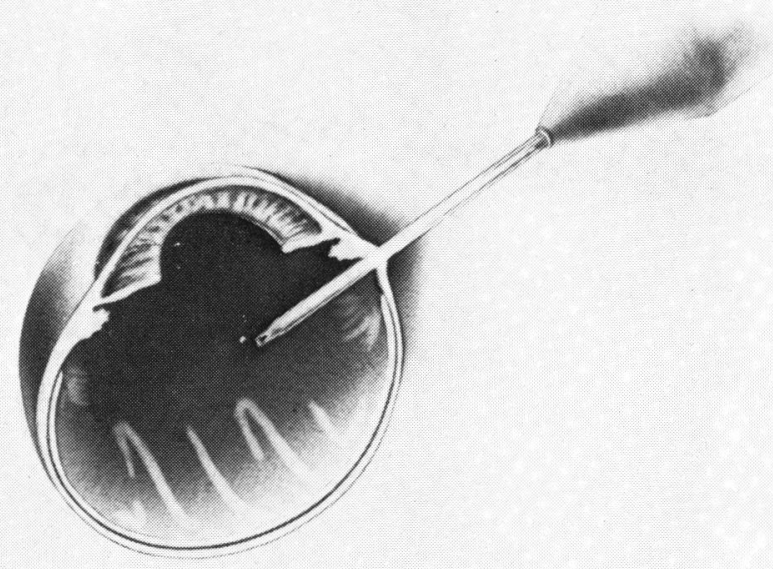

vitreous and is less than $1 \mathrm{~mm}$ in size, it can be sucked through the tip of the vitrophage (Fig. 3). If the IOFB is medium sized, a pair of infusing vitreous forceps is introduced through a second

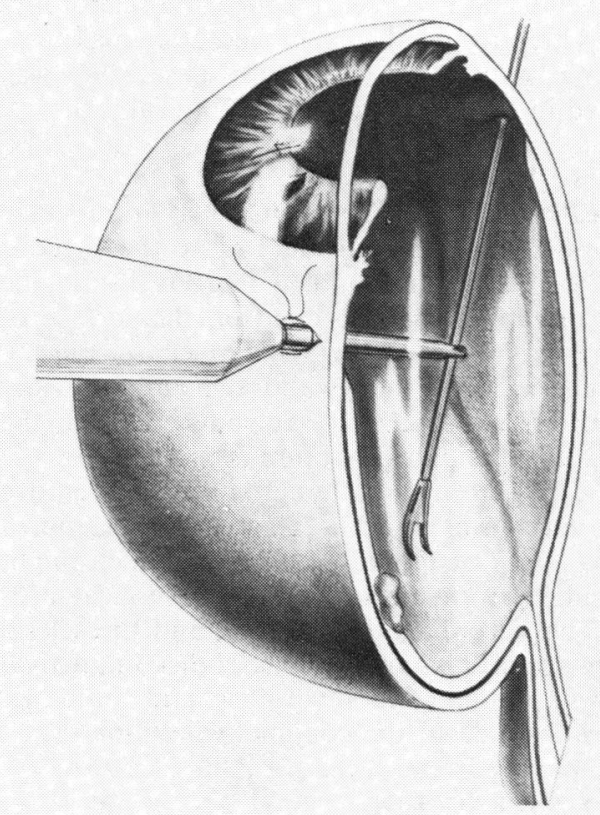

Fig. 4 Extraction by vitreous forceps of intraocular foreign body embedded in retina. sclerotomy. After clearing the media and cutting fibrous adhesions around the IOFB, the IOFB is removed with the vitreous forceps (Fig. 4).

When an IOFB is too large to be removed through the sclerotomy, it is removed through a clear corneal incision (Fig. 5). While the assistant holds the IOFB with the vitreous forceps and the vitrophage in position the surgeon makes a clear corneal incision and removes the IOFB with the use of conventional forceps. After removal of the vitreous forceps the corneal incision is closed with 9-0 nylon suture. Vitrectomy is then completed. If the IOFB has

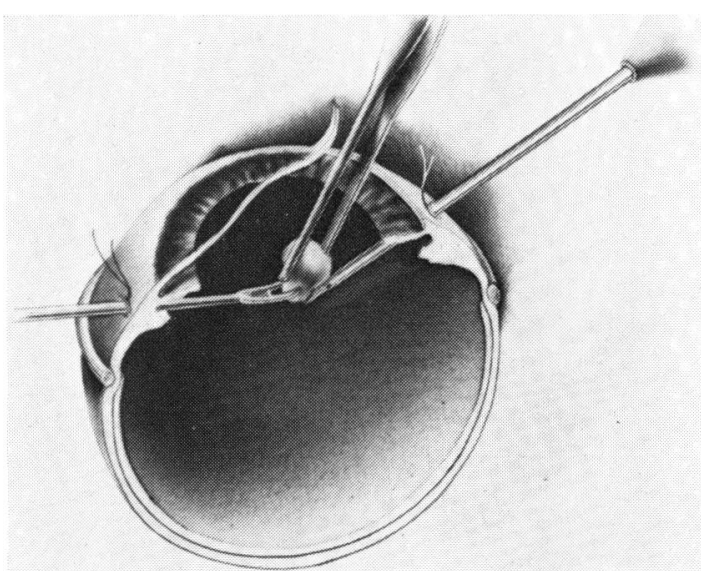

Fig. 5 Clear corneal extraction of large intraocular foreign body brought into the pupillary area by vitreous forceps. 


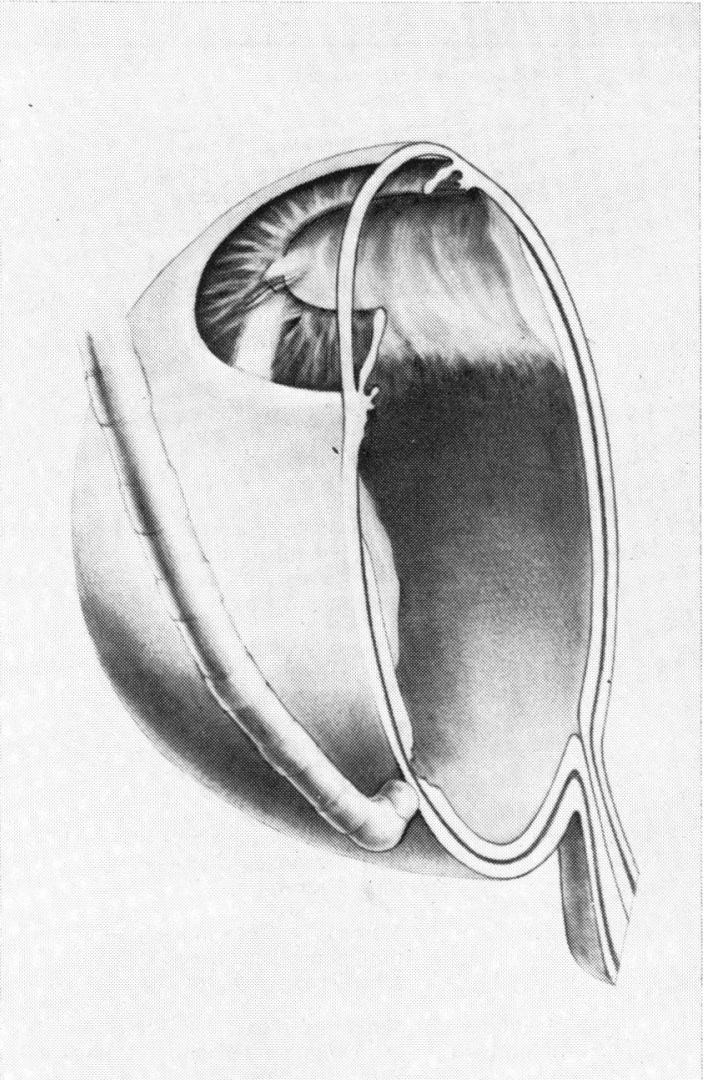

Fig. 6 Cryocoagulation around the area of a retinal injury.

injured the retina, cryocoagulation and scleral buckling of the injured site are performed (Figs. 6 and 7).

\section{Results}

GROUP 1

Of 11 patients 5 had IOFBs that were magnetic and 6 had IOFBs that were nonmagnetic (Table 1). Of the nonmagnetic IOFBs 1 was glass and 5 were various metals. Visual improvement occurred in 10 eyes postoperatively (Table 1 ). Four eyes had a retinal injury caused by the IOFB. Owing to extensive injuries 1 retina could not be reattached. The retinal injury was successfully treated in the remainder without developing postoperative retinal detachment. Surgical complications included minimal bleeding from the iris in 2 cases. In 1 patient a transient rise in intraocular pressure could be controlled by medical management. Follow-up ranged from 4 months to 5 years.

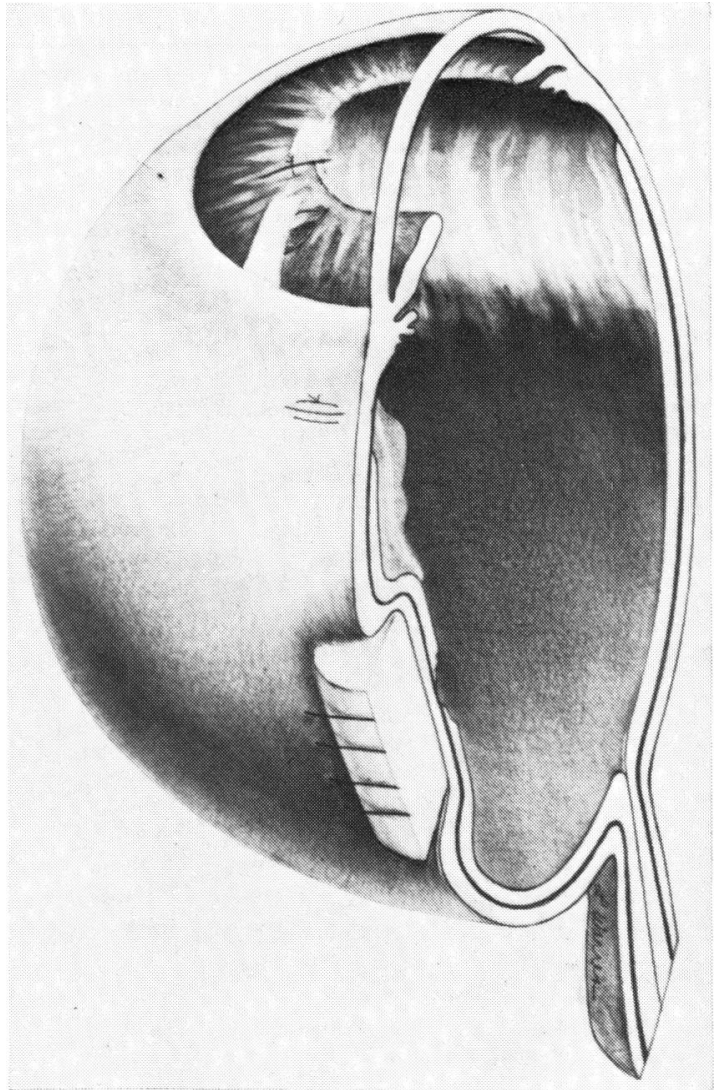

Fig. 7 Exoplant placed over the retinal tear.

\section{GROUP 2}

This group consisted of 3 cases in whom the IOFBs were not removed at the time of initial trauma. Patients were referred to us within a time interval of 1 to 4 years after the original injury. The nature of the IOFB was not known. Preoperative electroretinogram (ERG) showed no evidence of toxicity to the retina. In these patients pars plana lensectomy and vitrectomy for traumatic cataracts and vitreous opacities were done. In all these cases at the time of surgery we found a small encapsulated IOFB embedded in the retina (Fig. 8). The vitreous adhesions to the foreign bodies were cut. Because of the size of the IOFB, the long duration following the initial trauma, and the normal ERG, it was felt that aggressive removal of these IOFBs might be too traumatic to the retina. Thus they were not removed. There were no operative or postoperative complications. Visual acuity improved in all 3 cases (Table 2). Follow-up ERG examinations have remained normal over a period of 47 to 60 months. 
Table 1 IOFB removal with vitrectomy-lensectomy and retinal detachment repair

\begin{tabular}{|c|c|c|c|c|c|c|c|c|}
\hline $\begin{array}{l}\text { Case } \\
\text { no. }\end{array}$ & $\begin{array}{l}\text { Age } \\
(y r)\end{array}$ & $\begin{array}{l}\text { Type of } \\
\text { IOFB }\end{array}$ & $\begin{array}{l}\text { Preoperative } \\
\text { visual acuity }\end{array}$ & $\begin{array}{l}\text { Postoperative } \\
\text { visual acuity }\end{array}$ & $\begin{array}{l}\text { Follow-up } \\
\text { (months) }\end{array}$ & $\begin{array}{l}\text { Retinal damage } \\
\text { present }\end{array}$ & $\begin{array}{l}\text { Operative } \\
\text { procedure }\end{array}$ & Comment \\
\hline 1 & 21 & $\begin{array}{l}\text { Metal } \\
\text { (nonmagnetic) }\end{array}$ & $20 / 400$ & $20 / 40$ & 65 & $\begin{array}{l}\text { Retinal hole } \\
\text { with localised } \\
\text { detachment }\end{array}$ & $\begin{array}{l}\text { IOFB removal through } \\
\text { the vitrophage tip of } \\
\text { pars plana vitrectomy- } \\
\text { lensectomy and retinal } \\
\text { detachment repair }\end{array}$ & $\begin{array}{l}\text { Retina } \\
\text { attached }\end{array}$ \\
\hline 2 & 43 & $\begin{array}{l}\text { Metal } \\
\text { (nonmagnetic) }\end{array}$ & $20 / 400$ & $20 / 40$ & 59 & None & $\begin{array}{l}\text { IOFB removal through } \\
\text { the tip of vitrophage } \\
\text { pars plana vitrectomy- } \\
\text { lensectomy }\end{array}$ & - \\
\hline 3 & 21 & $\begin{array}{l}\text { Metal } \\
\text { (nonmagnetic) }\end{array}$ & Hand motions & $20 / 30$ & 51 & None & $\begin{array}{l}\text { IOFB removal by } \\
\text { vitreous forceps, pars } \\
\text { plana vitrectomy- } \\
\text { lensectomy }\end{array}$ & - \\
\hline 4 & 38 & $\begin{array}{l}\text { Metal } \\
\text { (magnetic) }\end{array}$ & $\begin{array}{l}\text { Counting } \\
\text { fingers }\end{array}$ & $\begin{array}{l}\text { Light } \\
\text { perception }\end{array}$ & 50 & $\begin{array}{l}\text { Total retinal } \\
\text { detachment, } \\
\text { retinal tear }\end{array}$ & $\begin{array}{l}\text { Electromagnetic extrac- } \\
\text { tion, pars plana vitrec- } \\
\text { tomy-lensectomy, retinal } \\
\text { detachment repair }\end{array}$ & $\begin{array}{l}\text { Irreparable } \\
\text { retinal } \\
\text { detachment }\end{array}$ \\
\hline 5 & 21 & $\begin{array}{l}\text { Metal } \\
\text { (magnetic) }\end{array}$ & $\begin{array}{l}\text { Counting } \\
\text { fingers }\end{array}$ & $20 / 30$ & 37 & None & $\begin{array}{l}\text { Electromagnetic extrac- } \\
\text { tion, pars plana virect- } \\
\text { tomy-lensectomy }\end{array}$ & - \\
\hline 6 & 30 & $\begin{array}{l}\text { Metal } \\
\text { (magnetic) }\end{array}$ & $5^{\prime} / 200$ & $20 / 60$ & 31 & None & $\begin{array}{l}\text { Electromagnetic extrac- } \\
\text { tion, pars plana vitrec- } \\
\text { tomy-lensectomy }\end{array}$ & - \\
\hline 7 & 35 & Glass & $\begin{array}{l}\text { Light } \\
\text { perception }\end{array}$ & $20 / 30$ & 31 & None & $\begin{array}{l}\text { Electromagnetic extrac- } \\
\text { tion, pars plana vitrec- } \\
\text { tomy-lensectomy }\end{array}$ & 一 \\
\hline 8 & 8 & $\begin{array}{l}\text { Metal } \\
\text { (magnetic) }\end{array}$ & $\begin{array}{l}\text { Counting } \\
\text { fingers }\end{array}$ & $20 / 25$ & 30 & None & $\begin{array}{l}\text { Vitreous forceps extrac- } \\
\text { tion, pars plana vitrec- } \\
\text { tomy-lensectomy }\end{array}$ & - \\
\hline 9 & 39 & $\begin{array}{l}\text { Metal } \\
\text { (nonmagnetic) }\end{array}$ & $\begin{array}{l}\text { Counting } \\
\text { fingers }\end{array}$ & $20 / 50$ & 29 & $\begin{array}{l}\text { Retinal hole } \\
\text { with localised } \\
\text { retinal } \\
\text { detachment }\end{array}$ & $\begin{array}{l}\text { Vitreous forceps } \\
\text { extraction, pars plana } \\
\text { vitrectomy-lensectomy, } \\
\text { retinal detachment repair }\end{array}$ & $\begin{array}{l}\text { Retina } \\
\text { attached }\end{array}$ \\
\hline 10 & 19 & $\begin{array}{l}\text { Metal } \\
\text { (nonmagnetic) }\end{array}$ & Hand motions & $20 / 30$ & 17 & None & $\begin{array}{l}\text { Vitreous forceps extrac- } \\
\text { tion, pars plana } \\
\text { vitrectomy-lensectomy }\end{array}$ & - \\
\hline 11 & 39 & $\begin{array}{l}\text { Metal } \\
\text { (magnetic) }\end{array}$ & $20 / 40$ & $20 / 50$ & 7 & $\begin{array}{l}\text { Retinal holes } \\
\text { with localised } \\
\text { retinal } \\
\text { detachment }\end{array}$ & $\begin{array}{l}\text { Electromagnetic extrac- } \\
\text { tion, pars plana vitrec- } \\
\text { tomy-lensectomy, retinal } \\
\text { detachment repair }\end{array}$ & - \\
\hline
\end{tabular}

\section{GROUP 3}

Twelve patients were referred to us for management of complications after the removal of an IOFB. Referrals occurred from 1 week to 4 years after initial surgery. Deterioration of visual acuity was attributed to traumatic cataract in 4 eyes, vitreous haemorrhage in 1 , and tractional and traumatic retinal detachment in 7 eyes. All 4 eyes with traumatic cataracts showed visual improvement better than $20 / 50$ postoperatively. The 1 eye with old vitreous haemorrhage showed visual improvement to $20 / 30$ (Table 3). Of the 7 retinal detachments 2 were successfully reattached; visual acuity improved to 20/200 (Table 3). Traction on the macula accounted for reduced visual acuity in these 2 cases. In 5 cases removal of the cataractous and vitreous 
Table 2 Pars plana vitrectomy-lensectomy without removal of IOFB due to retinal encapsulation

\begin{tabular}{llllllll}
\hline $\begin{array}{l}\text { Case } \\
\text { no. }\end{array}$ & $\begin{array}{l}\text { Age } \\
(y r)\end{array}$ & $\begin{array}{l}\text { Type of } \\
\text { IOFB }\end{array}$ & $\begin{array}{l}\text { Preoperative } \\
\text { visual acuity }\end{array}$ & $\begin{array}{l}\text { Postoperative } \\
\text { visual acuity }\end{array}$ & $\begin{array}{l}\text { Follow-up } \\
\text { (months) }\end{array}$ & $\begin{array}{l}\text { Interval between } \\
\text { injury and referral } \\
\text { (months) }\end{array}$ & Operative procedure \\
\hline 1 & 18 & Metal & $20 / 70$ & $20 / 20$ & 60 & 48 & Pars plana vitrectomy-lensectomy \\
2 & 20 & Metal & Counting fingers & $20 / 25$ & 48 & 29 & Pars plana vitrectomy-lensectomy \\
3 & 21 & Mctal & $20 / 300$ & $25 / 50$ & 47 & 17 & Pars plana vitrectomy-lensectomy \\
\hline
\end{tabular}

Table 3 Vitrectomy for sequelae of IOFB removal

\begin{tabular}{|c|c|c|c|c|c|c|c|c|}
\hline $\begin{array}{l}\text { Case } \\
\text { no. }\end{array}$ & $\begin{array}{l}\text { Age } \\
(y r)\end{array}$ & $\begin{array}{l}\text { Type of } \\
\text { IOFB }\end{array}$ & $\begin{array}{l}\text { Preoperative } \\
\text { diagnosis }\end{array}$ & $\begin{array}{l}\text { Interval between } \\
\text { initial surgery and } \\
\text { referral (months) }\end{array}$ & $\begin{array}{l}\text { Preoperative } \\
\text { visual acuity }\end{array}$ & $\begin{array}{l}\text { Postoperative } \\
\text { visual acuity }\end{array}$ & $\begin{array}{l}\text { Follow-up } \\
\text { (months) }\end{array}$ & Comment \\
\hline 1 & 9 & $\begin{array}{l}\text { Metal } \\
\text { (magnetic) }\end{array}$ & Traumatic cataract & 25 & $20 / 400$ & $20 / 40$ & 62 & - \\
\hline 2 & 31 & $"$ & $\begin{array}{l}\text { Old vitreous } \\
\text { haemorrhage }\end{array}$ & 7 & $20 / 70$ & $20 / 20$ & 60 & - \\
\hline 3 & 14 & , & Traumatic cataract & 7 & $20 / 200$ & $20 / 30$ & 50 & - \\
\hline 4 & 24 & ", & $\begin{array}{l}\text { Tractional retinal } \\
\text { detachment }\end{array}$ & 14 & $\begin{array}{l}\text { Light } \\
\text { perception }\end{array}$ & $20 / 200$ & 48 & Dragged macula \\
\hline 5 & 35 & , & Traumatic cataract & 24 & $20 / 300$ & $20 / 50$ & 38 & - \\
\hline 6 & 24 & , & , & 48 & $20 / 400$ & $20 / 25$ & 36 & - \\
\hline 7 & 43 & Glass & $\begin{array}{l}\text { Tractional retinal } \\
\text { detachment }\end{array}$ & 36 & $\begin{array}{l}\text { Counting } \\
\text { fingers }\end{array}$ & $\begin{array}{l}\text { Hand } \\
\text { motions }\end{array}$ & 30 & MPP \\
\hline 8 & 47 & $\begin{array}{l}\text { Metal } \\
\text { (magnetic) }\end{array}$ & $\begin{array}{l}\text { Large retinal tear and } \\
\text { retinal detachment }\end{array}$ & 1 week & $\begin{array}{l}\text { Counting } \\
\text { fingers }\end{array}$ & $4^{\prime} / 200$ & & " \\
\hline 9 & 49 & " & $"$ & , & $\begin{array}{l}\text { Light } \\
\text { perception }\end{array}$ & $\begin{array}{l}\text { Light } \\
\text { perception }\end{array}$ & 28 & , \\
\hline 10 & 50 & $"$ & , & 2 & Hand motions & $20 / 200$ & 24 & Macular folds \\
\hline 11 & $2 \frac{1}{2}$ & Glass & ” & 11 & $*$ & $*$ & 24 & MPP \\
\hline 12 & 18 & Copper & " & 2 & $\begin{array}{l}\text { Counting } \\
\text { fingers }\end{array}$ & $\begin{array}{l}\text { Counting } \\
\text { fingers }\end{array}$ & 24 & " \\
\hline
\end{tabular}

"Child. MPP $=$ Massive preretinal proliferation.

opacities revealed that the ocular injuries had been extensive, and end stage massive preretinal proliferation (MPP) was present. Postoperative complications included transient increase in intraocular pressure in 3 eyes, which was controlled by medical means. Follow-up ranged from 2 to 5 years.

\section{Discussion}

Magnetic IOFBs are easier to manage surgically than nonmagnetic IOFBs. However, many surgical and postoperative complications can occur in both. In a large series reported by Percival ${ }^{78}$ following pars plana removal of IOFB late complications included cataract $(54 \%)$, vitreous haemorrhage $(37 \%)$, and retinal detachment $(20 \%)$. Direct posterior removal of IOFBs with use of a magnet was performed in 61 cases. In this group 53\% developed cataracts, $39 \%$ had vitreous haemorrhage, and $20 \%$ had retinal detachments. In addition there was a $20 \%$ failure in removal of the IOFB at the first attempt. ${ }^{8}$

Automated vitrectomy instruments have greatly aided the management of cases with IOFBs. ${ }^{16}$ Lens opacities and vitreous haemorrhage, bands, and membranes can be removed at the time of surgery. The extent of retinal damage can be accurately assessed, and appropriate treatment can be carried out. Late postoperative complications are generally then minimised, as shown in our series.

In group 1 of our series 10 of 11 eyes treated by primary vitrectomy showed visual improvement. 
Four of these eyes had retinal injury. In 3 eyes the retinal surgery was successful and had no complications over a follow-up period of 4 months to 5 years. In 1 eye, owing to the extensive nature of the injury. the retina could not be reattached.

In group 2 of our series 3 eyes had retained IOFB. After performing lensectomy-vitrectomy we did not remove the IOFBs because they were small, firmly encapsulated, and embedded in the retina. Preoperative ERGs had not shown evidence of retinal toxicity. There was a delay of up to 4 years in referral of these patients to us. Had these cases been seen shortly after the acute trauma we would probably have attempted to remove the IOFB. Interestingly, in these cases there was no preretinal membrane formation or tractional retinal detachment in spite of the retinal injury and retained of IOFB. Follow-up studies in these eyes by means of ERG examination have not shown any sign of retinal toxicity, and the eyes continue to maintain good visual acuity. These cases show that not every retinal injury leads to a retinal detachment. However, these injuries had apparently not caused extensive vitreous haemorrhage. Possibly the presence of extensive amounts of blood in the vitreous might have stimulated growth of fibrous tissue and subsequent retinal detachment. ${ }^{17}{ }^{18}$ An initial decision to perform vitrectomy would depend on the extent of vitreous haemorrhage and the extent of retinal injuries. We do not consider vitrectomy to be urgently necessary when the media are clear enough to allow surgical removal of IOFB and allow examination of the fundus. In our opinion a retinal injury, if seen, should be cryocoagulated, and scleral buckling should be performed. Such cases may be referred later to a vitreous surgeon for vitrectomy if necessary.

Perhaps the extent and nature of the ocular injury in group 3 patients were not recognised at the time of removal of the IOFBs. The cloudy media might not have permitted adequate assessment of the intraocular pathology. Also, later changes in the vitreous could have contributed to the eventual tractional retinal detachments. Vitrectomy during the initial surgical procedure might have reduced these late complications. However, in selected cases in this category it is possible to remove vitreous traction and cut preretinal membranes by pars plana vitrectomy to allow the retina to become reattached.

This investigation was supported in part by a grant from the Lions of Illinois Foundation, Chicago, training grant EY703802 and core grant 1P30EY01792 from the National Institutes of Health, Bethesda, Md.

\section{References}

${ }^{1}$ Shipman JS, Delaney JH, Seeley RH. Magnet extraction of intraocular foreign bodies by anterior and posterior routes: A survey of 150 cases. Am J Ophthalmol 1953; 36: 620 .

${ }^{2}$ Rubinstein K. Intraocular foreign bodies: Report of 102 cases. Br J Ophthalmol 1954; 38: 369-77.

${ }^{3}$ McCaslin MF. The management of intraocular foreign bodies. Arch Ophthalmol 1960; 64: 482-93.

${ }^{4}$ Cridland N. Magnetic extraction. In: Roper Hall MJ, ed. Internation Ophthalmology Clinics. Boston: Little Brown, 1968: 8: 213-29.

${ }^{5}$ Barkan O, Barkan H. Experiences in extraction of magnetic foreign bodies. Am J Ophthalmol 1927; 10: 919-21.

${ }^{6}$ Trevor-Roper PD. Late results of removal of intraocular foreign bodies with magnet. $B r J$ Ophthalmol 1944; 28: 361-5.

'Percival SPB. A decade of intraocular foreign bodies. Br J Ophthalmol 1972; 56: 454-61.

${ }^{8}$ Percival SPB. Late complications from posterior segment intraocular foreign bodies: with particular reference to retinal detachment. Br J Ophthalmol 1972; 56: 462-8.

${ }^{9}$ Hutton WL, Synder WB, Vaiser A. Vitrectomy in the treatment of ocular perforating injuries. Am J Ophthalmol 1976; 81: 733-9.

${ }^{10}$ Peyman GA, Huamonte HU, Rose M. Management of traumatic retinal detachment with pars plana vitrectomy, scleral buckling, and gas injection. Acta Ophthalmol (Kbh) 1975; 53: 731-7.

${ }^{11}$ Conway BP, Michels RG. Vitrectomy techniques in the management of selected penetrating ocular injuries. Ophthalmology 1978; 85: 560-83.

${ }^{12}$ Peyman GA, Dodich NA. Experimental vitrectomy: Instrumentation and surgical technique. Arch Ophthalmol 1971; 86: 548-51.

${ }^{13}$ Peyman GA, Huamonte F. A disposable vitrectomy instrument: the vitrophage. Can J Ophthalmol 1975; 10: 281-5.

${ }^{14}$ Peyman GA, Sanders DR. Advances in Uveal Surgery, Vitreous Surgery and the Treatment of Endophthalmitis. New York: Appleton-Century-Crofts, 1975.

${ }^{15}$ Huamonte FU, Peyman GA, Goldberg MF. Complicated retinal detachment and its management with pars plana vitrectomy. Br J Ophthalmol 1977; 61: 754-60.

${ }^{16}$ Paton D, Goldberg MF. Management of Ocular Injuries. Philadelphia: Saunders, 1976.

${ }^{17}$ Cleary PE, Ryan SJ. Method of production and natural history of experimental posterior penetrating eye injury in the Rhesus monkey. Am J Ophthalmol 1979; 88: 212-20.

${ }^{18}$ Cleary PE, Ryan SJ. Histology of wound, vitreous and retina in experimental posterior penetrating eye injury in the Rhesus monkey. Am J Ophthalmol 1979; 88: 221-31. 